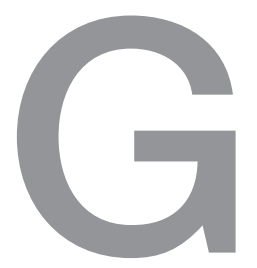

German
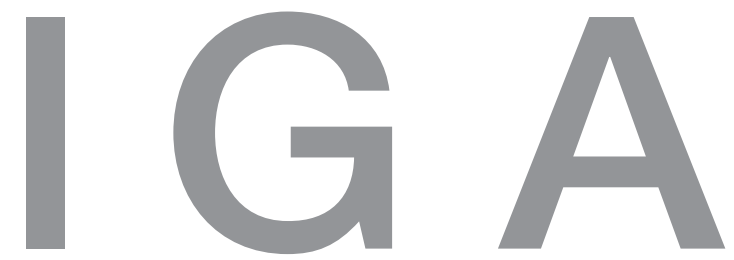

Working Papers

Leibniz-Institut für Globale und Regionale Studien

GIGA Research Programme:

Transformation in the Process of Globalisation

The Successful Ghana Election of 2008 a Convenient Myth?

Ethnicity in Ghana's Elections Revisited

Heinz Jockers, Dirk Kohnert, Paul Nugent

No 109

September 2009 
GIGA WP 109/2009

\section{GIGA Working Papers}

Edited by the

GIGA German Institute of Global and Area Studies

Leibniz-Institut für Globale und Regionale Studien

The GIGA Working Papers series serves to disseminate the research results of work in progress prior to publication in order to encourage the exchange of ideas and academic debate. An objective of the series is to get the findings out quickly, even if the presentations are less than fully polished. Inclusion of a paper in the GIGA Working Papers series does not constitute publication and should not limit publication in any other venue. Copyright remains with the authors. When working papers are eventually accepted by or published in a journal or book, the correct citation reference and, if possible, the corresponding link will then be included on the GIGA Working Papers website at <www.giga-hamburg.de/ workingpapers $>$.

GIGA research unit responsible for this issue:

Research Programme: "Transformation in the Process of Globalisation"

Editor of the GIGA Working Papers series: Martin Beck <beck@giga-hamburg.de>

Copyright for this issue: (C) Heinz Jockers, Dirk Kohnert, Paul Nugent

English copy editor: Carl Carter

Editorial assistant and production: Vera Rathje/Silvia Bücke

All GIGA Working Papers are available online and free of charge on the website $<w w w$. giga-hamburg.de/workingpapers $>$. They can also be ordered in print. A cover fee of $€ 5$ will be charged for production and postage. For orders or any requests please contact:

E-mail: workingpapers@giga-hamburg.de

Phone: ++49(0)40 - 42825 - 548

The GIGA German Institute of Global and Area Studies cannot be held responsible for errors or any consequences arising from the use of information contained in this Working Paper; the views and opinions expressed are solely those of the author or authors and do not necessarily reflect those of the Institute.

GIGA German Institute of Global and Area Studies

Leibniz-Institut für Globale und Regionale Studien

Neuer Jungfernstieg 21

20354 Hamburg

Germany

E-mail: info@giga-hamburg.de

Website: www.giga-hamburg.de 


\title{
The Successful Ghana Election of 2008 - a Convenient Myth? Ethnicity in Ghana's Elections Revisited
}

\begin{abstract}
Ghana's 2008 elections have been hailed by national and international observers as a model for Africa. This perception has prevailed despite persistent concerns about "ethnic block voting" and electoral fraud. Electoral malpractice and vote rigging along ethnic lines in Ghana's virtual two-party system could regain decisive importance as a "third force" that could tip the balance in future, possibly coming to represent an even more important factor than the smaller opposition parties. Unfortunate diplomatic and technocratic biases in election monitoring, combined with a reluctance on the part of the responsible authorities to investigate irregularities in what appears to be a long history of fraudulent "ethnic block voting", amounts to a dangerous time bomb of unresolved conflict which could explode in future elections.
\end{abstract}

Keywords: elections, ethnicity, election observation, informal institutions, impunity, Ghana JEL codes: D72, N47, Z1

\section{Heinz Jockers}

an ethnologist, Ph.D., Hamburg, is a consultant on African affairs and works for the EU, government bodies and NGOs.

Contact: h.jockers@gmx.de

\section{Dirk Kohnert}

an economist, is deputy director of the Institute of African Affairs (IAA) at the GIGA German Institute of Global and Area Studies in Hamburg, Germany. He was managing editor of the institute's scholarly journal Afrika Spectrum from 1991 to 2009. Prior to this, he worked as a lecturer in Development Planning at Bielefeld University, Germany. He has long-standing professional experience as a senior development expert and has worked in several African countries.

Contact: kohnert@giga-hamburg.de

Website: http://staff.giga-hamburg.de/kohnert

\section{Paul Nugent}

is a professor of Comparative African History and director of the Centre of African Studies at the University of Edinburgh. He is president of the Africa-Europe Group for Interdisciplinary Studies (AEGIS), chair of the steering committee of the ESF-African Borderlands Research Network (ABORNE) and scholarly advisor to several Africanist journals.

Contact: Paul.Nugent@ed.ac.uk

Website: www.shc.ed.ac.uk/history/staff/pnugent.htm 


\section{Zusammenfassung}

\section{Die erfolgreichen Wahlen in Ghana 2008 - ein zweckdienlicher Mythos?}

\section{Die Rolle von Ethnizität bei den Wahlen in Ghana wird erneut diskutiert}

Die Wahlen in Ghana 2008 werden von nationalen und internationalen Beobachtern als ein Vorbild für Afrika gelobt. Diese Auffassung steht im Gegensatz zur anhaltenden Besorgnis wegen Stimmenabgabe en bloc und Wahlbetrug. Auf Ethnizität zurückzuführende Wahlfälschung kann im faktischen Zwei-Parteien-System Ghanas als Zünglein an der Waage eine größere Bedeutung als „dritte Kraft“ gewinnen als die kleineren Oppositionsparteien. Bedauerliche diplomatische und technokratische Einseitigkeit bei der Wahlbeobachtung, kombiniert mit der Scheu verantwortlicher Behörden vor einer Untersuchung vermutlich jahrelang praktizierter ethnischer Blockabstimmung und jahrelangen Wahlbetrugs, bilden eine gefährliche Zeitbombe ungelöster Konflikte, die in künftigen Wahlen explodieren könnte. 


\title{
The Successful Ghana Election of 2008 - a Convenient Myth? Ethnicity in Ghana's Elections Revisited
}

\author{
Heinz Jockers, Dirk Kohnert, Paul Nugent
}

\begin{abstract}
Article Outline
1 Ghana's 2008 Elections - a Showcase for Africa?

2 Diplomatic and Technocratic Bias in Election Observation in Ghana's 2008 Elections?

3 The Case of Ashanti Region

4 The Case of Volta Region

5 Conclusion
\end{abstract}

\section{Ghana's 2008 Elections - a Showcase for Africa? ${ }^{1}$}

Successive democratic elections in Ghana in 1996, 2000, 2004 and 2008 resulted in two peaceful transfers of power between the major political parties (in 2000 and 2008) as well as in continuing improvements in the performance of its formal institutions, notably the Electoral Commission (EC), the judiciary and security forces. There was also a demonstrable increase in the oversight function of civil-society organisations and the media. The outcome of the parliamentary and presidential elections of December 2008 was hailed by stakeholders, the national and international media and diplomatic missions as another step forward in consolidating multi-party democracy in Ghana and as a model for the whole of Africa (cf. GyimahBoadi 2009; Loetzer/Moenikes 2009: 95). Yet 'ethnic block voting' remained a concern, at least

\footnotetext{
Thanks for valuable comments go to Steve Tonah, Sebastian Elischer and Darion Wachholz. The responsibility for any fallacies or inaccuracies in the paper remains, of course, with the authors. The latter participated in the 2008 elections as international election observers with the EU Election Observation Mission and the Carter Center respectively. The views are those of the authors alone.
} 
in the strongholds of the two major contesting parties, ${ }^{2}$ despite a long-standing tradition within Ghanaian political culture of frowning on ethnic appeals and despite various provisions within the constitution and the electoral law (Political Parties Act of 2000) designed to prevent 'tribalism' (cf. Loetzer/Moenikes 2009: 77). Observers of the 2008 elections deplored the 'growing ethnization' of Ghanaian politics, which is considered to be a heavy burden of the country's ongoing democratization process (cf. Loetzer/Moenikes 2009: 78). ${ }^{3}$

There exists a long-standing controversy about 'ethnic block voting' and how important swing voting has been in Ghana's Fourth Republic (1992-2009). Although the size of the core voting population in Ghana had been considerable, at least in the 1996 and in the 2000 elections (about 82 per cent of the voting population) which brought about the first democratic alternation of power, it was not overwhelming, thus refuting assumptions that voting volatility in transitional regimes is higher than in consolidated democracies (cf. Lindberg /Morrison 2005: 565). Apart from ethnicity, ${ }^{4}$ core and swing voters cannot be distinguished by structural factors like their level of education, income, occupation or the rural-urban divide. In the meantime, the percentage of swing voters might have increased. Nevertheless, strong 'ethnic block voting' in two regions has persisted: The regions of Ashanti (NPP) and Volta (NDC) (cf. Morrison/Hong 2006: 235, 239; Fridy 2007: 282, 286-9) have never voted against the political tradition of their region (i.e. the Busia-Danquah tradition in Ashanti and the opposing Nkrumahist tradition in Volta), ${ }^{5}$ a trend which was confirmed in 2008, although electoral volatility differs significantly even here (8.8 per cent in Ashanti and 17.4 per cent in Volta; cf. Lindberg/Morrison 2005: 570). ${ }^{6}$ Together both regions represent a significant proportion of all registered voters $(12,472,758$ in Ghana in 2008). Ashanti has the second-largest proportion of voters at 18.5 per cent, behind Greater Accra with 20.2 per cent. The Volta region accounts for 8.1 per cent; the population of the three northern regions combined is only 15.4 per cent (base 2008 election figures of the Electoral Commission, or EC). As regards core and swing voters, the Central Region (8.2 per cent of registered voters) was a notable example, because

2 As expected, the contesting major parties and their candidates attainted their best results, with the highest voter turnout in their respective strongholds: Nana Akufo-Addo, leader of the National Patriotic Party (NPP) gained 75 per cent in Ashanti, and Atta Mills, presidential candidate of the National Democratic Congress (NDC), got 86 per cent in Volta region, also labelled the 'World Bank' of the NDC by party veteran and former head of state Jerry Rawlings (cf. graph 1).

3 According to Gyimah-Boadi, "both parties shamelessly attempted to mobilize ethnic votes, virtually declaring their respective strongholds - the Ashanti Region for the NPP and the Volta Region for the NDC - as 'no-go' zones for their opponents" during the run-off to the presidential election on 28 Dec. 2008 (Gyimah-Boadi 2009: 143).

4 Unfortunately, Lindberg and Morrison could not test for ethnic block voting because of lack of time and reliable data (cf. Lindberg /Morrison 2005: 577).

5 However, in the early 1950s the Togoland Congress, which was allied with the NLM, did capture around half of the vote.

6 Long-standing local divisions and loyalties also had an impact in Northern Ghana; they vary in their intensity, but nevertheless continue to shape general political and specific electoral behaviour significantly (cf. Kelly/ Bening 2007). 
in 2008 the Fante-Akan majority abandoned the NPP for the NDC, apparently for non-ethnic reasons. ${ }^{7}$

The history of Ghana's electoral processes shows that, at least in popular perception, ethnicity matters more than any other socio-economic variable (cf. Fridy 2007: 281, 302; Tonah 2009). Fortunately, during these (and previous) elections it did not result in large-scale election violence as in other African states, like Kenya or Nigeria. ${ }^{8}$ However, the menace of bloody conflicts is also omnipresent in Ghana: the outbreak of the Dagomba and Konkomba conflict in Northern Ghana in 1994 proved that 'tribalist' conflicts can easily escalate into lethal confrontations with thousands of deaths (cf. Bogner 2000). In 2008, violent confrontations in Bawku between Kusasis and Mamprusis threatened to become politicized in this manner, but fortunately this was avoided. All it takes is for chieftaincy and land disputes to become linked to party political alignments to produce an explosive mixture.

The second area of ongoing concern lies in claims and counter-claims about electoral fraud. Although the total number of votes involved was possibly quite small, the closeness of the result meant that vote massing could well have jeopardized the legitimacy of the process. The most recent elections proved again that Ghana is virtually a two-party system possibly because of the peculiarities of its British-style electoral system (with multiple single-member constituencies; cf. Morrison/Hong 2006: 631-2), reinforced by competing Ghanaian political traditions based on ideology and related socio-economic divisions between 'Nkrumahists' and 'Busia-Danquahists'. Expectations that one of the smaller opposition parties could break through as a third force were again disappointed (see Figure 1). ${ }^{9}$

7 The Central Region voted for the NDC in 1992 and 1996, and altered to the NPP in 2000 and 2004. There were 'swings' against the NPP in Brong-Ahafo and in its favour in parts of the North, too.

8 However, the 'Yendi massacre' of 2002 and its aftermath of violent chieftaincy disputes among the Dagomba in the Northern Region was also an issue with strong ethnic undertones in the national 2004 elections, when according to the then vice-president - 'the whole North was on fire'. The violent conflict was seen by many Dagbon as just another injustice perpetrated by the then governing party (NPP) (cf. MacGaffey 2004: 79, 81, 98).

9 In the parliamentary election of 7 December 2008, the governing National Patriotic Party (NPP) lost its absolute majority in parliament and won only 107 of the 230 seats overall. The major opposition party, the National Democratic Congress (NDC), secured victory with 114 delegates winning most mandates, but failed to win an absolute majority, with two constituencies still pending. The People's National Convention (PNC) only secured two seats and the Nkrumahist Convention People's Party (CPP) just one - for the daughter of Ghana's first head of state, Kwame Nkrumah; in addition, four independent parliamentarians won a seat.

In the first round of the presidentials (7 December 2008), the candidate of the NPP, Nana Akufo-Addo won 49.13 per cent, the leader of the NDC, John Evans Atta Mills, 47.92 and Paa Kwesi Nduom of the CPP 1.34 per cent. In the run-off elections of 28 December, Atta Mills narrowly won with 50.23 per cent of the valid votes, while 8 out of 10 regions voted for him. He was declared the new president elect by the EC on 3 January 2009 and inaugurated in compliance with constitutional provisions on 7 January 2009 (cf. EU-EOM 2009: 31-2). 
Figure 1: Ghana 2008, Presidential Run-off Elections: Number of Valid Votes, Share of Each Candidate, and Turnout (in per cent) per Region

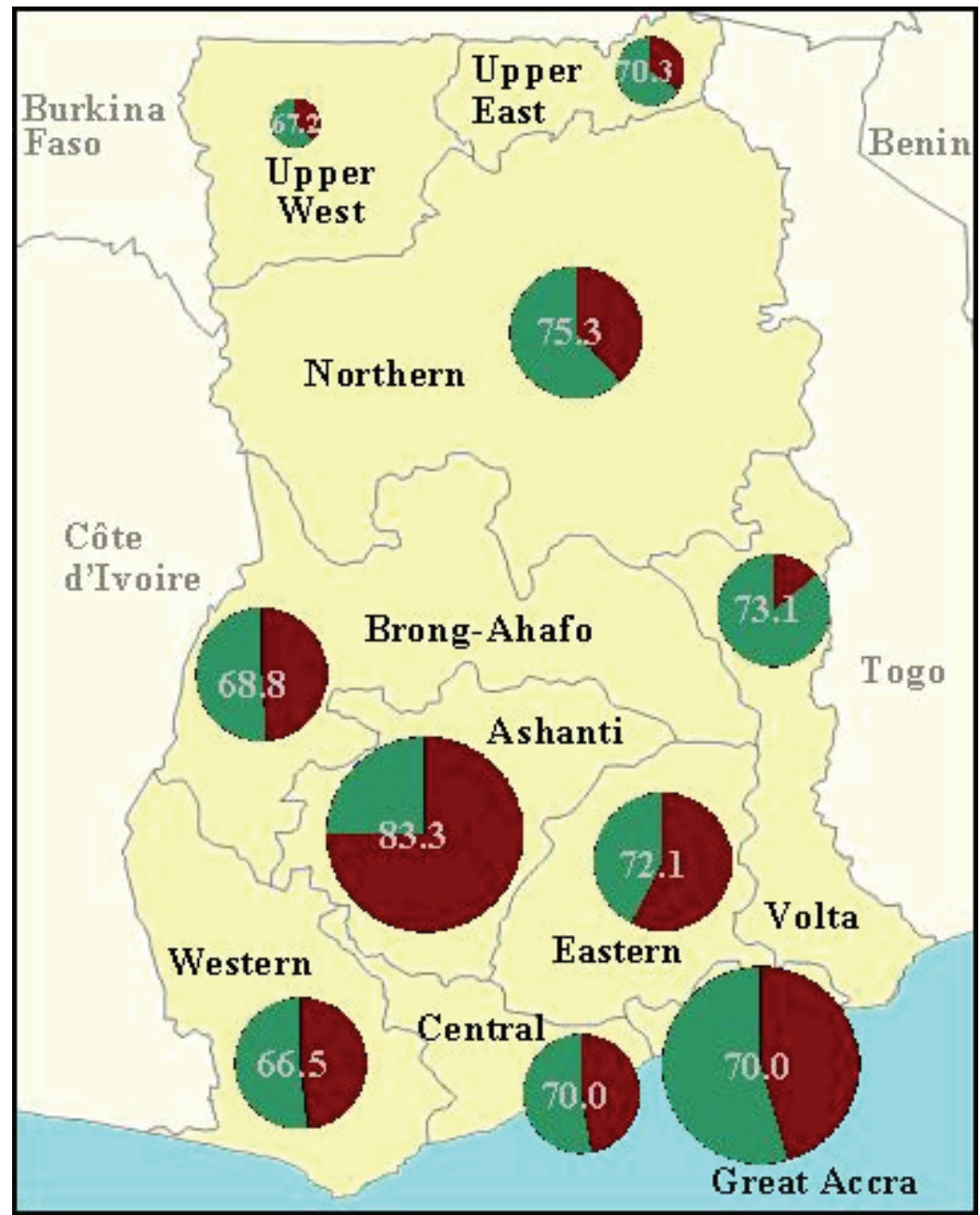

\section{Atta-Mills (NDC) Number of Votes}

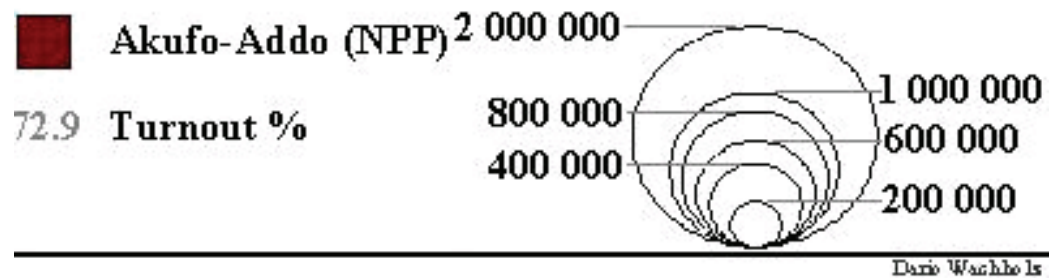

Source: EC Ghana.

The vast majority of voters view the two major parties, the National Democratic Congress (NDC) and the New Patriotic Party (NPP), as mainly representing Ewe and Ashanti interests respectively (cf. Loetzer/Moenikes 2009: 64, 78). However, in reality, the relationship between ethnic politics and partisanship is far more complex than that; factors other than ethnicity, notably socio-economic issues, dominate the actual voting patterns in Ghana, with the possible exception of Ashanti and Volta (cf. Fridy 2007; Lindberg/Morrison 2008; Nugent 2001a). Cer- 
tainly, the Ashanti-Ewe divide and the overall dominance of the Akan group ${ }^{10}$ in economic and social life as well as in the public sector contribute to ethnic and regional polarization in Ghana (cf. Asante/Gyimah-Boadi 2004: 125-7). But neither the Ashanti nor the Ewe group is big enough to pose a threat of domination in electoral politics, as they constitute just 15 per cent and 13 per cent of the population respectively. In addition, the apparent pattern of block voting in Ashanti and the Volta region cannot be explained by ethnic considerations alone, given that both regions are not just populated by Ashanti or Ewe voters (cf. Asante \& E. Gyimah-Boadi 2004; Nugent 2001). Thus, a mixture of ethnic, regional and socio-economic factors, notably marginalization and 'class' issues, constitutes the basis of voting patterns, which is obscured by the language of ethnicity (cf. Elischer 2008; Fridy 2007; Lindberg/Morrison 2008; Nugent 2001: 3-6). Yet it was probably the introduction of multi-party democracy in 1992 that polarized the country and exacerbated its 'ethnic' conflicts (cf. Tonah 2009). This might have been accentuated by the instrumentalization of ethnic affiliation and the 'politics of belonging' within the framework of a growing new nationalism and the accompanying implicit policy of excluding 'foreigners' (cf. Kuba/Lentz 2006; Kohnert 2009).

Ghana's history reveals recurrent attempts to deny 'non-authentic' ethnic groups, e.g. the Ewe and the Konkomba, their 'Ghanaianness' (cf. Amenumey, 1989; Nugent 2002). The Akan power elite that dominated the state was already portraying the Ewe as tribalists, oppositionists and secessionists in the 1970s, whereas the Ewe elite branded the Ashanti as aggressive and arrogant. Although these stereotypes were not mirrored by everyday life, they were nevertheless nourished as powerful ideological myths by those in both groups who had vested interests (cf. Brown 2000: 20, 29, 116-18). ${ }^{11}$ Non-Ewe minorities, e.g. in Volta Region, took sides in this 'ethnic antagonism' out of political expediency by aligning themselves with larger partners (cf. Nugent 2000: 163, 180 on 'ethnicity by approximation').

All considered, 'ethnic block voting' and vote rigging along ethnicity lines could regain decisive importance in Ghana, possibly even more importance as a 'third force' than the smaller opposition parties. The sheer number of votes that can be mobilized by each group may serve as an indicator: the difference between valid votes in the first and second round in Ashanti Region amounted to 241,284. The candidate of the largest of the small opposition parties, Paa Kwesi Nduom of the Convention People's Party (CPP), gained 113,494 votes in the first round of the 2008 presidential election, and in the final round just 40,586 votes tipped the scale in favour of Atta Mills.

10 Making up 49.1 per cent of the country's population, the Akan are the largest ethnic group in Ghana, including the sub-group of the Ashanti. The terminology is fraught with problems, however, because the Ashanti might be regarded as an ethnic group in their own right.

11 For examples related to the 2008 elections, cf. the controversy in Ghanaweb on “Ethnocentricity, and Ghana's Fragile Democracy", cf. http: //ghanaweb.net/GhanaHomePage/features/artikel.php?ID=125214, accessed on 2 June 2009. 
Against the backdrop of growing conflicts due to a new nationalism informed by the politics of belonging in Africa in general, and recent electoral violence in Kenya and Nigeria in particular, praise for the peaceful 2008 elections in Ghana is understandable. However, despite the impression of generally free and fair elections, serious malpractices and electoral fraud apparently occurred, notably in relation to the highly problematic voter registration and voter turnout figures (cf. EU-EOM 2009: 15, 29; CODEO 2008: Table 1). Again, the most contested results came from Ashanti and the Volta Region. Not all the allegations of the contesting parties or the Coalition of Domestic Election Observers (CODEO) were investigated sufficiently, as will be shown in the following chapters. The international community inside and outside Africa was at pains to have a positive example to hold up, a model to follow for Ghana's African peers. ${ }^{12}$ Slightly critical remarks were rare, like those made by the EU Electoral Observers with respect to the implausibly high turnout in six Ashanti constituencies and the lack of transparency in the transmission of aggregated figures (cf. EU EOM 2009: 29). The EC, which would have been responsible for in-depth investigations, shied away for unknown reasons from opening this can of worms. Possibly it lacked both time and resources for a thorough investigation or it thought it wiser not to touch these questions because they would not affect the overall results. However, although comprehensible in view of the tense political situation at that time, this neglect could seriously distort the picture of what actually took place and threaten Ghana's political stability and democratic consolidation in the medium and long term. This is the more so because it was apparently not the first time that the EC disregarded probable election rigging, notably in Ashanti, Volta and the Northern Region, where similar unusually high turnout figures of over 90 per cent of the registered voters were recorded in the 2004 presidential elections. Could it be that supervisors and international observers of the 2008 Ghanaian elections were equally blinded by the quest for an African success story? Whatever the truth of the matter, the outcome is fraught with perils for the future. Because both the NDC and the NP believe that the other side perpetrated fraud in their strongholds and got away with it, it is highly likely that they will try to do so on an even greater scale in 2012. This raises the prospects of electoral violence and the de-legitimation of the electoral process unless the matter is squarely dealt with.

\section{Diplomatic and Technocratic Bias in Election Observation in Ghana's 2008 Elections?}

The peaceful and largely transparent outcome of the 2008 elections was to a large extent due to the strong commitment and active engagement of Ghana's media and civil society, who monitored and commented on the electoral process with great zeal. Think tanks, advocacy

12 Ghana was the first country to pass the African Peer Review Mechanism (APRM), a self-monitoring mechanism implemented by the African Union (AU) (cf. Herbert/Gruzd 2008). This happened in 2006. 
groups, religious and professional organisations and NGOs comprised an impressive platform of independent coverage of the polling process - assisted by advanced technology, meant for regular updates of local and regional results, parallel vote tabulation via mobilephone text messages and local radio stations (cf. Gyimah-Boadi 2009: 145-6; Loetze/Moenikes 2009: 80-2). The CODEO was the largest domestic observer group, deploying over 4,000 observers throughout the country on both election days. Its contribution in validating the process was of fundamental importance. In addition, the major parties employed party agents as observers in most of the 21,007 polling stations, which greatly enhanced transparency at the grass-roots level and during the aggregation of the results (cf. EU-EOM-2009: 25). The large and visible presence of foreign media and diverse groups of international observers, including the EU, the Carter Center, the African Union, the Pan-African Parliament, the Commonwealth and the Economic Community of West African States (ECOWAS) contributed to increased public confidence in the process as well. In view of the disappointing experiences with rigged elections in Nigeria and Zimbabwe in the recent past, the bloody ethnic clashes in the aftermath of the Kenyan elections, and coups in Guinea and Mauretania, international observers naturally displayed an interest in looking for a contrasting successful example of free and fair elections. Their overall evaluation of the 2008 Ghanaian election reflected these subliminal considerations. Overriding concerns about political stability in the sub-region and conflict prevention, in view of the volatile political situation in neighbouring Côte d'Ivoire and Togo, may have enhanced this predilection. An additional technocratic bias (cf. Kohnert 2004 for details), notably a disregard for Ghanaian election history as well as informal politics (cf. below) and a focus exclusively and excessively on formal procedures of multi-party democracy, apparently blinded impartial analyses even more regarding the realities on the ground.

One case in question is the long-standing controversy about the inflated voter register and its connection with the unusually high turnout figures in the run-off election in numerous constituencies of the Ashanti, Volta and Northern Regions in the 2004 and 2008 presidential elections. ${ }^{13}$ Controversies over the integrity of the voters' register were a regular feature in

13 See below for detailed turnout figures concerning the 2008 elections. In the 2000 presidential elections - the first democratic polls which brought about an alternation of power (from the NDC to the NPP this time) and which were also highly contested - the turnout was relatively low. This was attributed at the time to a bloated voter register. On the national level, valid votes accounted for only $60.8 \%$ in the first run and $59.7 \%$ in the second one. But even here, Ashanti and the Volta Region scored highest, with $64.3 \%$ (65.0\%) and 59.7\% (67.8\%) respectively (cf. Smith 2002: 629, also for a detailed discussion of differences of voter turnout in Ashanti and Volta in the 2000 elections). However, there is no correlation between conspicuous constituencies in Ashanti and the Volta region in the 2008 elections, compared with the presidential polls in 2004 or 2000.

In general, high voter turnout is no longer associated with flawed elections per se, as in times of despotic or 'socialist' regimes in Africa: in many African countries people continue to put great value on the act of political participation, at least in national elections, despite often disappointing performances by elected representatives. 
Ghana's elections and even led to political crises in some cases. For example, the 1992 elections were marred by opposition allegations (mostly unfounded) about a 'stolen verdict', followed by the opposition's boycott of the December legislative polls (cf. Jeffries/Thomas 1993). The voter's register had also been grossly inflated in the 2000 elections, especially in Greater Accra, Ashanti and the Volta region. The reasons given focused on double registration in different regions and the fraudulent registration of minors and deceased persons as major problems, resulting in an estimated 1.5m 'ghost voters' (cf. Smith 2002: 624-31). Even during the 2008 election campaign, 349,496 entries out of a total of 12,822,474 registered voters were removed by the EC because they were considered to be irregular (cf. also EU-EOM 2009: 14-16). ${ }^{14}$ CODEO said in a statement issued on 4 August 2008 that violence during voter registration and irregularities had been "widespread". ${ }^{15}$ In view of a persistently bloated register, notably in Ashanti and the Volta region, the abnormally high turnout figures are even more questionable as they might be due last but not least to mobilized 'ghost voters'.

Although barely credible turnout figures were criticized in the final report of the EU Election Observation Mission, ${ }^{16}$ even this criticism was not as exhaustive as it might have been. It goes without saying that although the quoted turnout figures are highly doubtful, they are especially hard to falsify with robust facts and figures under present conditions in Ghana or elsewhere in Africa (cf. Kuenzi/Lambright 2007; Smith 2002; Lindberg 2008). In fact, a total of nine constituencies in Ashanti, two to four in Volta and one in Central, Eastern and Upper West Region each showed questionable results, with Ashanti being by far the greatest sus-

The overall national turnout only tends to drop (from $67 \%$ to $61 \%$ on average) after repeated flawed elections (cf. Lindberg 2008: 12-13). The official voter turnout in Sub-Saharan Africa ranged from 21.6\% in Mali's 2002 election to an almost certainly heavily flawed $99.4 \%$ in Niger's 1999 polls (cf. Kuenzi/Lambright 2007: 678).

14 The EC had expected to register an additional 800,000 voters since 2006, the year the register was last updated, which corresponded to estimates of the number of citizens who had attained voting age in the meantime. However, the 2008 provisional register listed nearly two million additional voters (cf. Ichino/Schündeln 2009: 5). Again, the highest increase in registered voters during the limited registration exercise of the EC (from 31 July to 13 August 2008) was to be observed in Ashanti Region: 374,451 new voters were recorded, which is an increase of $330.7 \%$ over the 2006 exercise. The provisional voter population for the region increased by $18.7 \%$ to $2,381,214$ voters compared with the electoral roll of 2006. For the whole of Ghana the total increase was $16.7 \%$, or 12,822,474 (cf. "Voters register hits 12.8 million", www.ghana.gov.gh/node/5615/print, accessed on 5 April 2009). Calculations by an NDC activist, based on incomplete preliminary data of the EC, checked against the figures of the 2000 Population and Housing Census of Ghana, resulted in an estimated inflation of the voter register of 890,011 at the national level in 2008. Together, Greater Accra and Ashanti Region accounted for about $92 \%$ of this over-registration (cf. Rojo Mettle-Nunoo, 27 Oct. 2008, comment on the article 'Ghana-Protecting the credibility of the Electoral Commission', <http://allafrica.com/comments/list/aans/post/id/200810271720.html>, accessed on 6 May 2009).

15 Cf. "Pre-election violence and irregularities worries watchdog", Ghana elections 2008, http://ghanaelections 2008.blogspot.com/2008/08/pre-election-violence-and.html, accessed on 19 June 2009.

16 "Turnout in five of the constituencies in Ashanti - Bantama, Kwadaso, Manhyia, Nhyiaeso, and Suame - also demonstrated unusually high numbers of votes cast, which was over 95 per cent of registered voters. In contrast to all other areas in the country, the lack of safeguards used by polling officials and an absence of transparency in the transmission of the aggregated results for these constituencies makes the accuracy of results from these areas open to question" (EU EOM 2009: 29). 
pected culprit (cf. Table 1, 2). ${ }^{17}$ A similar pattern was to be observed in the 2004 presidential elections when, for example, at least five constituencies in Ashanti produced dubious turnout rates, most of which were the same as in 2008. In the Northern Region the same was true of at least three constituencies, including two reporting 95 per cent or more and three in Volta Region. ${ }^{18}$ It is certainly not by chance that these inconsistencies recurred mainly in those regions where the influence of ethnicity on elections remains most virulent. Registration fraud and concomitant inflated turnout figures are probably more likely in party strongholds than in competitive areas (cf. Ichino/Schündeln 2009: 10, 16).

It is open to question whether the doubtful results had been cross-checked by the EC or other liable authorities and what action had eventually been taken to remedy the situation. In the best-case scenario, the unusually high turnout figures truly reflect the strong engagement of voters in the constituencies concerned. The worst-case scenario is that a history of impunity of election rigging, influenced by ethnicity in already volatile constituencies and regions, will encourage enhanced electoral fraud in future elections. Those who commented favourably on the elections pointed out that producing a legitimate result was a tremendous achievement by the Election Commissioner, Dr. Afari-Gyan. However, at the height of the disputed run-off, his strategy appears to have been to call the bluff of the NPP by accepting the questionable results from Ashanti and then pointing out that these were not enough to overturn the majority that had been chalked up by Mills. When the NPP insisted that the Tain constituency, where there had been no voting, could still affect the outcome, he called their bluff again and agreed not to declare the result until the election had been re-run there. No doubt, this was evidence of skilful footwork, but the point remains that the final result was arrived at by glossing over allegations of significant electoral fraud. The precedent that has been set is a dangerous one and there is no guarantee that a future Commissioner will be as fleet of foot as the last one.

\section{The Case of Ashanti Region}

There was never any doubt that the chances of the NPP being re-elected in 2008 hinged on retaining the absolute loyalty of the Ashanti region as a 'vote bank', as even the NPP itself readily admitted. One consideration was whether the NPP could retain the sympathy of vot-

17 The turnout figures in constituencies where one of the following three cases applies are considered questionable: (1) a turnout of over $95 \%$, (2) a turnout of over $90 \%$ along with an overwhelming number of votes (> $80 \%$ ) for one candidate, or (3) differences in votes cast between the first and second round of more than $10 \%$ with a high overall turnout $(>80 \%)$ in the second round. The latter is considered to be doubtful as well because it is unlikely that even the newly employed tactic of the NPP in its stronghold, i.e. vigorous house-tohouse campaigns dubbed "fre wo nua" (literally, call your brother to go and vote), could result in such a massive increase in the total number of additional voters within the short two-week-long election campaign between the first and second round.

18 Cf. the 2004 presidential election data sheets of the EC at www.ec.gov.gh/node/63, accessed on 29 April 2009. 
ers in parts of the region who were more recent converts to the party cause. In Ashanti, there have been two weak links for the NPP historically. One is at the geographical margins, reflecting deeper historical dynamics: in the 1996 presidential poll, the NDC won a majority in three constituencies in Northern Ashanti and two in the south. In the first round of the 2000 presidential election, only Ejura Sekyedumase and New Edubiase resisted the NPP. In the second round, head of state John Kufuor failed to carry the latter. If support for the government were to erode, there was a possibility of a reverse swing in these marginal constituencies. Secondly, Ashanti has witnessed considerable levels of northern in-migration. The Zongo communities have tended to vote NDC. Hence the Asawase parliamentary seat in Kumasi was captured by the NDC in 2004, despite its poor showing elsewhere.

A real concern for the NPP campaign team was that Ashanti voters might not turn out to vote for an Akyem presidential candidate, even if they remained broadly disposed to the NPP as a party. Hence turnout was always regarded as a prime consideration. Nana Akufo-Addo brought prominent Ashantis into his campaign in order to reassure voters that the party remained firmly rooted in its tradition as an Ashanti/Akyem alliance. The team staged big rallies in Kumasi and larger urban centres in an attempt to persuade voters that it retained enthusiastic support in the region. The fundamental question of how many Ashanti voters there actually were was dogged by controversy right from the start. Before the re-opening of the voters' register, the NDC complained that the figures for 13 Ashanti constituencies were massively inflated. In April, the EC set up an independent committee to investigate this claim. Dr. Afari-Gyan initially lent credence to NDC fears when he confirmed that the increase in the number of voters in Ashanti was not credible, but in June he revised his assessment. He announced that the incorrect figures, which were the result of a printing error, only existed in hard copies of the register that had been sent to parties and that they were not replicated in the EC's own database. Although this supposedly meant that there should be no further cause for concern, the NDC believed that any error was deliberate and would be brought into play later on. The problem was compounded when the register was re-opened to allow those who had attained full voting age to add their names. The NDC alleged that there had been systematic attempts to pump up the numbers in Ashanti through a combination of double and underage registration. The opposition parties therefore remained extremely sceptical about the figures in Ashanti. During the campaign, Rawlings not surprisingly returned to the claim that there was a plot to rig the election, centred on Ashanti. The fact that some large question marks remained about the process disposed many opposition supporters to believe the worst.

The election campaign in the region witnessed a few incidents of violence, but some of these involved rival candidates for NPP parliamentary nominations - as was the case in Bekwai. 
On the whole, the campaign passed off with little trouble. In the first round of voting in 2004, Kufuor had captured 1,235,395 out of 1,679,664 votes, which translated into 73.6 per cent of the votes in Ashanti. In the first round in 2008, Akufo-Addo won 1,214,350 out of 1,677,285 votes, amounting to 72.4 per cent. By contrast, Mills had won 398,362 of the votes in 2004 (23.7 per cent), whereas in 2008 this had increased to 438,234 votes, or 26.1 per cent (cf. Table 1). In other words, regional turnout had dipped slightly, but this was to Akufo-Addo's disadvantage. Mills had seen his total number of votes and his share of the Ashanti vote increase. The NDC had also managed to increase its number of parliamentary seats to three - New Edubiase. Ejura Sekyedumase and Asawase - while two NPP rebel candidates had won as independent candidates.

All of this was understandably a matter of considerable alarm to the NPP campaign team. Akufo-Addo's supporters privately complained that the relatively low turnout in Ashanti had cost Akufo-Addo a first-round victory which he only narrowly missed (with 49.1 per cent of the national vote). There was also some dissatisfaction at the failure of Kufuor to play a more active role on the campaign trail, which may have been rooted in his historically strained relationship with elements of the Ashanti political elite (Elischer 2008) and his earlier support for Alan Kyerematen as the party candidate. In the campaigning for the second round, Kyerematen, who had briefly resigned from the party, was brought in to head the campaign in Ashanti in the belief that he held the key to a higher turnout - despite being a Fante. A special appeal was made to Ashanti voters to prevent Rawlings from staging a comeback on the coat-tails of Mills. The Mills campaign meanwhile hoped to make modest gains in Ashanti, while consolidating the swing elsewhere.

In the final analysis, Akufo-Addo achieved what he was hoping for in Ashanti during the second round. The total vote in Ashanti rose to 1,880,372 with Akufo-Addo taking 1,401,421 (74.5 per cent) and Mills 478,749 (25.5 per cent). Akufo-Addo had therefore conjured up another 187,071 votes and increased his overall share, whereas Mills had increased his numbers by a mere 40,515 . If the balance of forces had remained the same in the other regions, the additional votes (just over one per cent of the total national vote) would have pushed AkufoAddo across the winning line. As it happened, the gains in Ashanti were wiped out by the swing to Mills in all the other regions, including Brong-Ahafo, which had gone to the NPP in round one. The question which arises is whether the NPP campaign team genuinely improved its performance in the second round or something untoward had happened. The results in certain constituencies do look extremely suspicious. At Manhyia where the recorded turnout was 95.7 per cent, the NPP vote rose from 66,116 in the first round to 95,281 in the second (+24 per cent). At Nhyiaeso, where the alleged turnout was 98.3 per cent, it rocketed from 37,043 to 54,545 (+26 per cent) and in Suame it climbed from 47,768 to 67,790 on a 95 per- 
cent turnout (+24 per cent; cf. Table 1). The total turnout figures for Ashanti (83.3 per cent) were out of line with the figures for the rest of the country (72.7 per cent). Interestingly, the turnout in Akufo-Addo's own region, that of the Eastern Region, stood at only 72.2 per cent. Given the closeness of the contest, these increases could have been enough to swing the overall result.

Perhaps voters in Ashanti genuinely feared a return of the NDC more than other Ghanaians. Yet recorded increases in electoral participation, leading to very questionable turnout figures at the constituency level, should have raised scepticism among international observers. It is unlikely that fraud occurred at the level of individual polling stations, given the strong presence of electoral observers. However, there may have been manipulation and intimidation in those polling stations or constituencies where NDC polling agents withdrew on polling day. The transmission of results from the constituency level to the Electoral Commission headquarters provides much broader scope for electoral rigging. This is confirmed by evidence in other countries where elections have taken a violent turn in the post-poll period. The claim that two different sets of results were received in the EC 'strongroom', with the second revealing much higher figures than the first, has never been properly explained. What is even more suspicious is that the regional office of the EC appears to have deliberately held back declaring a number of Ashanti results. ${ }^{19}$ By releasing the NPP's bombs at the end, the NDC claimed, it was possible to claim victory at the last gasp once it was known how many votes were still required to concoct a victory. There is some plausibility in this reading of what happened because a relatively comfortable Mills majority suddenly evaporated as the last results came in. It was not enough, as it happened, but the NPP came close to snatching victory at the last moment. Constituencies that declared late included the same ones where there was an implausible turnout, notably Nhyiaeso (98.3 per cent), Kwadaso (94.5 per cent), Manhyia (95.7 per cent) and Suame (94.7 per cent). ${ }^{20}$

The NDC complained about these figures, but after the Tain result was declared, Afari-Gyan announced on 3 January 2009 that the EC had investigated the complaints and concluded that the NDC had failed to produce sufficient evidence in the shape of complete polling station returns for the disputed constituencies. In reality, this was a mammoth task, especially as some of the polling agents had not been present at the final count. Although the NDC was still deeply unhappy, it had been declared the overall winner and decided to live with the

19 This comment is based on personal observation. Paul Nugent spent some time in the Electoral Commissioner's office on election day, and it was striking that a late release of results from Ashanti was being anticipated as a contentious issue.

20 This situation reminded one about the 2007 elections in Kenya, which resulted in a political coup and then 'civil war' with thousands of deaths and hundreds of thousands of IRPs. Although the situation in Kenya was different, e.g. Pro-Kibaki constituencies declared late due to their geographical location, this was also used to change result sheets. The Final Report of the EU-EOM provided one example. 
Ashanti anomalies rather than provoke a crisis. Since then, the EC has shown no inclination to revisit the issue. It has offered no explanation of the turnout figures, no reason for the late declaration of certain Ashanti results and has failed to publish a complete set of results on its website that would enable Ghanaians to judge for themselves. These are serious shortcomings that might come back to haunt the country in the future.

\section{The Case of Volta Region}

The hope of NPP activists in the Volta Region for a reversal of their fortunes was based on a number of considerations. In the 2004 elections, the party succeeded in winning a parliamentary seat in Nkwanta North for the first time. The constituency is situated in a minority area in the northern part of the region, where although Akan is used as a lingua franca, the different groups are not related to the Akan. The candidate was a medical doctor by profession and was very popular among the Dagomba, the biggest group in the constituency. The NPP strategy was accordingly focused on minority areas where they aspired to win at least four constituencies: Nkwanta North again, Nkwanta South, Krachi East and Krachi West as well as Ketu North in the southern part of the region where the Regional Minister was running. The NPP officials boasted of their concern for the welfare of the whole region: for example, they pointed out that their government had built a Polytechnic College in Ho which could significantly redress the perception of marginalization. Nevertheless, there was a common belief among people that public money had been diverted by a corrupt national government to other regions that were better endowed with basic infrastructure like roads, schools and hospitals. ${ }^{21}$ The NPP exploited the advantage of the incumbency in Volta Region. For example they were able to provide large numbers of T-shirts, schoolbooks in the villages, traditional presents for the chiefs and queen mothers, and also - at least according to usually well-informed local informants - cash as an incentive to vote for the 'right' candidate. Money was allegedly used to get registration officers 'on board'. ${ }^{22}$ The deal was said to involve the registration of anyone provided by the party with no questions asked, including 'minors', and to place potential opposition voters on a wrong list of voters. This was precisely what happened in Hohoe during the registration process where two employees of the Regional Electoral Commission (REC) were arrested by the police for manipulating voters' lists. ${ }^{23}$ According to information released by the police, the accused confessed having taken money from the NPP. However, no

\footnotetext{
21 In an Afrobarometer questionnaire - "How Ghanaians Rate the Performance of the NPP Administration" (Afrobarometer Briefing Paper No. 49, June 2008) - the Presidency is especially linked to corruption and government to inflation and income gaps. Although the data is taken nationwide, it probably applies to the Volta region as well.

22 This allegation is based on a strategy paper by the NPP giving hints on how to manipulate elections. Only a few of the things that actually took place are mentioned here.

23 A court case was fixed after the election.
} 
complaint about the registration process was brought to the knowledge of the EU observers. Other fraudulent practices concerned ballot papers meant for NDC strongholds that would be rendered useless by printing mistakes and subsequently be rejected by NPP party agents. This happened in a few places (e.g. in Nkwanta District), but its net effect was only to delay the voting process, not to hinder it. In addition, the NPP organized so-called 'Party Youth' in a number of constituencies like Krachi East, with the aim of harassing opposition and election officials. This happened in Dambai.

In the Regional NDC office the mood was the opposite. The atmosphere was very tense and party officials repeatedly came out with new press releases about planned fraud by their competitors - sometimes based on very questionable claims. They insisted that, for example in Dambai, houses of NDC members had been marked by NPP youths, thereby echoing what had happened in Rwanda. Yet no hard evidence could be presented to the observers.

The REC (Regional Electoral Commission) was able to secure an acceptable election process. Apart from Buem Constituency (District Jasikan), all the constituency result sheets had been signed by representatives from both parties. In Jasikan, NPP agents failed to turn up for the tabulation process. The Returning Officer claimed that NPP party officials told them to stay away. The results in Volta Region showed a landslide victory for the NDC: apart from Nkwanta North, ${ }^{24}$ all the other constituencies went to the NDC in the parliamentary polls. Many of the people with whom the EU observers spoke had anticipated a result like this. In all the districts or constituencies targeted by NPP, the party did better than ever before, and yet it was still far from achieving a majority. There were only minor incidents, like one in Krachi East where the car taking the ballot boxes to the regional office was attacked on the way and the boxes were stolen. Since the Presiding Officer had the signed result sheets, the REC was still able to announce the results.

An internal strategy paper of the NPP, ${ }^{25}$ which analysed the first-round defeat in the region and recommended new tactics for the presidential run-off, raised some points that should be outlined here. It claimed that the NPP in the districts had not been able to give a sufficient 'cash incentive' to REC officers, police and opinion leaders. Party agents were paid inadequately and were more prepared to accept money from other sources. Many polling agents were identified as active NDC members. ${ }^{26}$ This led to speculation about where the money from the party's headquarters had gone. The consequence for the regional NPP was that the

24 The NPP did not win by a large margin, which was due to a number of independent candidates who were able to win a substantial number of votes. The NDC secured the majority at the presidential election.

25 A copy of this paper was placed in the hands of the EU observers.

26 This argument was never brought to the knowledge of the EU observers. On the other hand, CODEO should have known since their observers came from the area, but did not mention it - perhaps because they were not represented well in the region. 
party's 'National Campaign Coordination' took over the party structure in the Volta region. But it leaves no doubt that money was part of the party's strategy in this area.

Not much was seen in the local arena regarding the forthcoming run-off, by contrast with the heated discussions on $\mathrm{TV}$, the radio and in the newspapers about electoral rigging in Volta and Ashanti. NPP officials claimed that the elections in the Volta Region had been marred by fraud and stressed that their party agents had been harassed and had not been allowed to take up their duties. Apparently, these general accusations were unfounded since their agents had signed all but one of the result sheets at the tabulation centres. It would have been easy for the REC in Ho to clarify all the accusations, but the EC answered solely in general terms and did not refer to any concrete allegations. ${ }^{27}$ In the end, it was part of the NPP's propaganda to discredit the NDC in the run-off.

Two days before the second round, a group of about a hundred so-called 'Macho Boys', i.e. NPP sympathizers, were brought in from Accra. When asked about their role in the election, the mainly young men claimed to be working as polling staff. Unfortunately, they had no idea about election procedures. ${ }^{28}$ They expected to secure their accreditation in the evening. ${ }^{29}$ They were brought to polling stations during voting day where they often met local party agents who refused to be replaced by them. ${ }^{30}$ Some of them first came to the assigned polling station by late afternoon. Names on the party's official list had often been replaced or were overwritten. This was the reason why many Presiding Officers did not allow them inside the polling station. Others who had been allowed inside later refused to sign the result sheets. ${ }^{31}$ Evidence procured by the REC ${ }^{32}$ as well as a number of oral confessions to the EU observers suggested that NPP party agents told them not to sign, although they actually could not give any concrete reason for their refusal. ${ }^{33}$ In short, the presence of the 'Macho Boys' caused a lot of ill-feeling in the Volta region, although in the end they did not have much effect since the procedures in place were working. But they gave reasons for the party's officials on the na-

27 This was left to the Press; but since journalists' movements were quite restricted because of financial constraints, many cases were left open.

28 The EU observers met them close to Kpando town where they were lodging and had a long discussion with a large number of them.

29 The NEC had decided to hand out badges as accreditation, but these did not have any numbers or names on them. A list of their names should have been given to the REC at least two days before the election, but this did not happen.

30 Only two agents per party were allowed inside the polling station.

31 The constituency result summary sheets were not signed by NPP agents in three cases: Ho Central, North Dayi and Keta, by NDC Nkwanta North, although the NDC got the majority. In Krachi East one PS out of 73 was left out (562 voters) because of faulty ballot papers and in Krachi West one PS (134 voters) out of 118 voting was disrupted. Both constituency result sheets were signed.

32 A written confession by one agent (PS Kpando no. 2 in South Dayi Constituency) saying that he was phoned by the Party Youth Secretary who told him not to sign.

33 The law says that if an agent refuses to sign, he has to state his reason for not doing so in a written form. This did not happen at any PS. 
tional level to come up with all kinds of accusations against the REC and NDC and play on people's fears. ${ }^{34}$ Nevertheless, compared to the first round where the NPP secured 9.2 per cent, their share rose to 13.94 per cent in the second round, while the NDC dropped from 88.64 to 86.06 per cent. What is open to speculation is the much higher turnout in the second round, namely a total of 739,669 votes as compared to 679,396 in the first round, amounting to an increase of 60,600 in the number of votes cast. Some of the increase in specific constituencies would warrant closer investigation by the REC or EC. ${ }^{35}$

In spite of the NDC's presidential candidate Prof. Mills being of Fante origin, people in the Volta region still associated the party with former President Rawlings, the NDC's grey eminence who has a partly Ewe background. The reason given for why a change of government was necessary was that the power had to be taken away from 'those people in Kumasi' who allegedly did not care about Volta Region - the poor road conditions were often invoked as evidence. ${ }^{36}$

An indicator of the NPP's role in Volta Region in the second round, as seen by the party's 'National Campaign Coordination', was the failure of national NPP party officials to show up during the pre-election period. Obviously the region had been written off. It appears that the operative strategy was to disturb the election procedures and - if the situation should permit - to use this in order to hinder the official announcement of the final presidential results if this was not in favour of the NPP.

Three days before voting took place, the government closed the border with Togo, obviously because of the suspicion that a number of Ewe people from Togo had registered and would vote in the interest of their kinsmen. The furious reaction by NDC officials showed that this distrust was not completely misplaced. ${ }^{37}$ Nevertheless, it is an example of how the parties took 'ethnic' factors into account. Significantly, no other border was closed.

The police were very reluctant to deal with actual conflicts like the one in Krachi East because they were afraid that their intervention might increase the tension, as was the case in the aftermath of conflicts with the Dagomba in the past. After all, they had been attacked in the Dagomba area and it was only thanks to the appearance of the military that disturbances were avoided in Dambai during the collation procedure. The festivities in Ho after the announcement of the NDC victory were very restrained. It may be a problem in future if all the

34 Paul Nugent and Tom Molony investigated NPP complaints of violence and intimidation in some Volta Region constituencies on behalf of the Carter Center, but no clear picture emerged. In one case, where serious allegations were made by the District Chief Executive, they encountered party executives from the NDC and NPP who were on extremely friendly terms.

35 11,167 more votes were cast in Ketu S., 4,792 in Anlo, 5,073 in Avenor, 4,786 in Tongu N., 4,495 in Ho C and 4,954 in Ho East, all of which are outstanding examples.

36 See Nugent 2001.

37 There has always been suspicion about the link between the Ewe on both sides of the Ghana-Togo border, including allegations of arms trafficking. 
party agents who allowed themselves to be misused fail to be taken to court despite their having broken the electoral law. It might be a good thing for ordinary voters to see them being taken to court in order to point out that the responsibility for proper conduct does not lie with party or government officials alone.

In short, (perceived) ethnicity continued to be a major underlying factor in the 2008 elections in Volta Region, as indicated by the block voting. So far, the traditional structures and their role in the election have been left out of analyses. As in most African societies, informal institutions, notably traditional authorities, play a bigger role than is generally taken into consideration by election observers. ${ }^{38}$ The question is whether and how far other ethnic groups would become embroiled in ethnic cleavages within the framework of future elections. It remains to be seen whether the NDC and NPP will honour the Code of Conduct of the political parties as well as the formal legal precautions against instrumentalization of ethnicity in politics in future elections.

\section{Conclusion}

Ghana's process of democratization is certainly more advanced than in many other countries in sub-Saharan Africa. Swing voting was generally significant enough in the past to produce changes of government and still is today. In addition, it has become more difficult for individuals and political parties to cheat in Ghana's elections despite persistent voting irregularities and widespread abuse of incumbency. Two factors are important in this respect: first, the EC has largely been seen as an independent, fair and credible institution, and second, the elite and large sections of the population were prepared to accept results declared by the EC. Nevertheless, neglected or unrecognized electoral fraud and a history of impunity - underscored by 'ethnicity' 39 in already volatile constituencies and regions of decisive importance for the general outcome of the polls - could encourage large-scale electoral fraud in future elections. This poses a threat and is a potentially destabilizing factor in Ghana's democratization process.

The Achilles' heel of election administration in Ghana was the dubious voters' register and the irresolute attitude of the EC and other responsible authorities when it came to the rechecking of improbably high voter turnouts and apparent 'ethnic block voting' in several

38 All the chiefs, queen mothers, herbalists and church authorities spoken to were convinced about a clear win for the NDC in Volta Region. Although they officially have a neutral position, in reality they play an active role, using informal structures usually closed to outsiders.

39 Again, we underline that the category of 'ethnicity' is problematic insofar as ethnic categories in Ghana are not that fixed. The Akan category, for example, is deeply problematic (cf. Nugent 2001). Nevertheless, 'ethnic cleavage' constitutes a deeply engrained emic view of the rule of politics in Ghana, so it has analytical value in its own right. 
constituencies. Surprisingly, neither of the big political parties seem to have bothered to insist on rigorous in-depth investigation once their complaints were rebuffed by the EC. Could it be that the instrumentalization of ethnicity for voting was a zero-sum game and that all concerned hoped to profit from it eventually? Or is ethnicity in Ghana still such a deadly issue that no-one dares touch it, lest it explode in his face?

Apparently, the constitutional and other legal provisions mentioned above to prevent 'ethnic block voting' were inadequate. It is open to question whether any refinement of these formal legal weapons to defend multi-party democracy can remedy the situation. In an environment where informal institutions in politics and economy are paramount (cf. Meagher 2007), formal political rules operate under severe constraints. A piecemeal but painstaking democratization of the fabric of informal politics, including chieftaincy (which seems to be deeply involved in 'ethnic block voting') and a meaningful decentralization policy would be required to lay a sustainable base for a functioning democracy at the grass-root level. However, past experience has shown that 'decentralization from above' cannot do the job; it prevents a genuine devolution of power, which, among other things, would require the structures of traditional authority to be realigned in accordance with basic democratic requirements (cf. Bacho 2005; Crawford 2008; Lentz 2006, Owusu 2009). In short, there is nothing that could replace political struggle for real democracy from below. 


\section{Bibliography}

Amenumey, D.E.K. (1989): The Ewe unification movement. A political history. Accra: Ghana University Press.

Asante, Richard/Gyimah-Boadi, E. (2004): Ethnic structure, inequality and governance of the public sector in Ghana. Geneva: United Nations Research Institute for Social Development (UNRISD).

Bacho, F.Z.L. (2005): Decentralization in a Pluralist State: Ethnic Identity, Resource Conflicts and Development in the East Gonja District of Ghana. Ghana Journal of Development Studies, 2 (1): 7-36.

Bogner, Arthur (2000): The 1994 civil war in Northern Ghana. The genesis and escalation of a "tribal" conflict, in: Lentz, Carola/Nugent, Paul (eds.): Ethnicity in Ghana. The limits of invention. Basingstoke: Macmillan, 2000: 183-203.

Brown, David (2000): Contemporary nationalism: civic, ethnocultural, and multicultural politics. London: Routledge.

CODEO (2008): Preliminary statement of Ghana's presidential election run-off held on Sunday, December 28, 2008. Accra: Coalition of Domestic Election Observers, www.codeogh.org/? $\mathrm{p}=213$, accessed on 19 June 2009.

Crawford, Gordon (2008): Decentralization and the Limits to Poverty Reduction: Findings from Ghana. Oxford Development Studies, 36 (2): 235-58.

Elischer, Sebastian (2008): Do African parties contribute to democracy? Some findings from Kenya, Ghana and Nigeria. Afrika Spectrum, 43 (2): 175-201.

EC - Electoral Commission of Ghana, www.ec.gov.gh/results, accessed on 20 April 2009.

EU EOM (2009): Ghana - Presidential and Parliamentary Elections 2008. Brussels: European Union Election Observation Mission (EU EOM), Final Report.

Frempong, Alexander, K.D. (2006): Ethnicity, democracy and Ghana's election 2004, in: Boafo-Arthur, K. (ed.), Voting for democracy in Ghana. The 2004 elections in perspective. Accra: Freedom Publications, : 157-86.

Fridy, Kevin, S. (2007): The elephant, umbrella, and quarrelling cocks: Disaggregating partisanship in Ghana's fourth republic. African Affairs, 106 (423): 281-305.

Gyimah-Boadi, E. (2009): Another step forward for Ghana. Journal of Democracy, 20 (1): 138-52.

Herbert, Ross/Gruzd, Steven (2008): The African Peer Review Mechanism: Lessons from the Pioneers. Johannesburg: South African Institute of International Affairs. 
Ichino, Nahomi/Schündeln, Matthias (2009): Preliminary results from a randomized field experiment on voter registration in Ghana 2008. Working Paper, Harvard University, March 26, www.yale.edu/cpworkshop/papers/Ichino.pdf, accessed on 5 April 2009.

Jeffries, Richard/Thomas, Clare (1993): The Ghanaian elections of 1992. African Affairs, 92: 331-66.

Kelly, Bob/Bening, R.B. (2007): Ideology, regionalism, self-interest and tradition: an investigation into contemporary politics in northern Ghana. Africa, 77 (2): 180-206.

Kohnert, Dirk (2009): Entfremdung und Ausgrenzung: Afrikas neuer Nationalismus in Zeiten der Globalisierung (Alienation and exclusion: Africa's new nationalism in times of globalization, in German). Sociologus, 58 (2): 197-222.

Kohnert, Dirk (2004): Caught Between Political Engineering and Diplomacy? Challenging demands for Election Observation in Africa - The case of founding elections in Nigeria and Madagascar. Review of African Political Economy, 31 (99): 83-101.

Kuba, Richard and Carola Lentz (eds.) (2006): Land and the Politics of Belonging in West Africa. Leiden: Brill.

Kuenzi, Michelle/Lambright, Gina M.S. (2007): Voter turnout in Africa's multiparty regimes. Comparative Political Studies, 40 (6): 665-90.

Lentz, Carola (2006): Decentralization, the State and Conflicts over Local Boundaries in Northern Ghana. Development and Change, 37 (4): 901-19.

Lindberg, Staffan I. (2008): Democratization by Elections-A New Mode of Transition? University of Florida, Department of Political Science, paper presented at Duke University, 27 October.

Lindberg, Staffan I./Morrison, Minion K.C. (2008): Are African voters really ethnic or clientelistic? Survey evidence from Ghana. Political Science Quarterly, 123 (1): 95-122.

Lindberg, Staffan I. / Morrison, M.K.C. (2005): Exploring voter alignments in Africa: core and swing voters in Ghana. Journal of Modern African Studies 43 (4): 565-86.

Loetzer, Klaus D. / Mönikes, Volker (2009): Präsidentschafts- und Parlamentswahlen in der Republik Ghana im Dezember 2008. KAS-Auslandsinformationen, 25 (1): 57-96.

MacGaffey, Wyatt (2006): Death of a king, death of a kingdom? Social pluralism and succession to high office in Dagbon, northern Ghana. Journal of Modern African Studies, 44 (1): $79-99$.

Meagher, Kate (2007): Informal institutions and development in Africa. Introduction. Special issue of Afrika Spectrum, 43 (3): 405-18. 
Morrison, Minion K.C. / Jae Woo Hong (2006): Ghana's political parties: how ethno/regional variations sustain the national two-party system. Journal of Modern African Studies, 44 (4): $623-47$.

Nugent, Paul (2002): Smugglers, secessionists and loyal citizens on the Ghana-Togo frontier. Oxford: James Currey.

Nugent, Paul (2001): Ethnicity as an explanatory factor in the Ghana 2000 elections. African Issues, 29 (1-2): 2-7.

Nugent, Paul (2001a): Winners, losers and also rans: money, moral authority and voting patterns in the Ghana 2000 election. African Affairs, $100: 405-28$.

Nugent, Paul (2000): "A few lesser peoples": the Central Togo minorities and their Ewe neighbours, in: Lentz, Carola/Nugent, Paul (eds.): Ethnicity in Ghana: the limits of invention. London: Palgrave Macmillan, 162-82.

Nugent, Paul (1999): Living in the past: urban, rural and ethnic themes in the 1992 and 1996 elections in Ghana. Journal of Modern African Studies, 37 (2): 287-319.

Owusu, George (2009): Internal boundaries and district administration: A challenge to decentralization and district development. Geografiska Annaler: Series B, Human Geography, 91 (1): 57-71.

Smith, Daniel A. (2002): Consolidating democracy? The structural underpinnings of Ghana's 2000 elections. Journal of Modern African Studies, 40 (4): 621-50.

Tonah, Steve (2009): Democratization and the resurgence of ethnic politics in Ghana 1992-2006, in: Rosenthal/Bogner (eds.), forthcoming. 


\section{Annex}

Table 1: Ghana's 2008 Presidential Elections:

Ashanti Region, Results of Doubtful Validity

[1st round (7.12.2009) and run-off $\left.(28.12 .2009)^{(\mathrm{a})(\mathrm{c})}\right]$

\begin{tabular}{|c|c|c|c|c|c|c|c|c|c|c|}
\hline \multicolumn{2}{|l|}{ Ashanti } & \multicolumn{2}{|c|}{$1^{\text {st }}$ round } & \multicolumn{3}{|c|}{$2^{\text {nd }}$ round } & \multicolumn{4}{|c|}{ turnout $\%$} \\
\hline Constituency & $N P P$ & $N D C$ & \begin{tabular}{|l|} 
valid votes \\
\end{tabular} & turnout $\%$ & reg. voters & $N P P$ & $N D C$ & valid votes & turnout $\%$ & $2^{n d}-1^{s t} r d$ \\
\hline Afigya/Sekyere East & 33,855 & 9,240 & 43,623 & 77.29 & 57,040 & 40,788 & 9,641 & 50,429 & 89.15 & +12 \\
\hline Bantama $^{(b)}$ & 40,493 & 7,649 & 48,690 & 70.90 & 69,215 & 56,227 & 8,532 & 63,759 & 93.81 & +23 \\
\hline Atwima-Kwanwoma & 33,324 & 6,013 & 39,766 & 77.69 & 51,995 & 39,147 & 6,564 & 45,711 & 88.42 & +11 \\
\hline Kwabre East & 43,329 & 10,473 & 54,288 & 75.06 & 73,222 & 50,502 & 11,796 & 62,298 & 85.68 & +11 \\
\hline Kwadaso $^{(b)}$ & 44,341 & 8,069 & 52,950 & 70.65 & 75,488 & 62,110 & 8,876 & 70,986 & 94.47 & +24 \\
\hline Manhyia $^{(b)}$ & 66,116 & 18,835 & 85,896 & 71.47 & 121,082 & 95,281 & 20,210 & 115,491 & 95.71 & +24 \\
\hline Nyiaeso S.M. ${ }^{(b)}$ & 37,043 & 10,464 & 48,243 & 71.98 & 67,540 & 54,545 & 11,681 & 66,266 & 98.29 & +26 \\
\hline Old Tafo & 34,887 & 12,243 & 47,543 & 72.05 & 66,676 & 47,476 & 13,416 & 60,892 & 91.62 & +20 \\
\hline Suame ${ }^{(b)}$ & 47,768 & 9,344 & 57,687 & 69.70 & 82,758 & 67,790 & 10,368 & 78,158 & 94.73 & +24 \\
\hline Total & $1,214,350$ & 438,234 & $1,677,285$ & 73.58 & $2,317,686$ & $1,438,820$ & 479,749 & $1,918,569$ & 83.31 & 9.73 \\
\hline
\end{tabular}

Notes: (a) Results of turnout over $95 \%$, or over $90 \%$ and overwhelmingly for one candidate, or difference in turnout between $1^{\text {st }}$ and $2^{\text {nd }}$ round $>10 \%$.

(b) Constituencies also questioned by EU EOM Ghana 2008, final report.

(c) $1^{\text {st }}$ round, preliminary results.

Source: Electoral Commission of Ghana (EC); authors' own compilation.

Table 2: Ghana's 2008 Presidential Elections:

Volta Region, Results of Doubtful Validity

[1st round (7.12.2009) and run-off $\left.(28.12 .2009)^{(\mathrm{a})(\mathrm{c})}\right]$

\begin{tabular}{|c|c|c|c|c|c|c|c|c|c|c|}
\hline Volta & \multicolumn{5}{|c|}{$1^{\text {st }}$ round } & \multicolumn{4}{|c|}{$2^{\text {nd }}$ round } & turnout \% \\
\hline Constituency $^{(b)}$ & $N P P$ & $N D C$ & valid votes & turnout \% & reg. voters & $N P P$ & NDC & valid votes & turnout $\%$ & $2^{n d}-1^{s t} r d$ \\
\hline Ho East & 1,373 & 21,168 & 23,235 & 67.44 & 35,233 & 1,836 & 26,605 & 28,441 & 81.50 & +14 \\
\hline Anlo & 863 & 31,153 & 32,462 & 70.63 & 46,653 & 1,328 & 36,207 & 37,535 & 80.88 & +10 \\
\hline Keta & 1,000 & 28,846 & 30,188 & 72.26 & 42,303 & 1,057 & 33,693 & 34,750 & 82.63 & +10 \\
\hline Ketu South & 2,815 & 56,484 & 60,238 & 62.52 & 98,283 & 3,415 & 68,595 & 72,010 & 73.88 & +11 \\
\hline Total & 99,538 & 551,046 & 664,888 & 67.12 & $1,012,122$ & 102,173 & 630,899 & 733,072 & 73.11 & \\
\hline
\end{tabular}

Notes: (a) Results of turnout over $95 \%$, or over $90 \%$ and overwhelmingly for one candidate, or difference in turnout between $1^{\text {st }}$ and $2^{\text {nd }}$ round $>10 \%$.

(b) Constituencies also questioned by EU EOM Ghana 2008, final report.

(c) $1^{\text {st }}$ round, preliminary results.

Source: Electoral Commission of Ghana (EC); authors' own compilation. 


\section{G

\section{Recent Issues}

No 108 Sebastian Huhn: The Culture of Fear and Control in Costa Rica (II): The Talk of Crime and Social Changes

No 107 David Shim: Shrimp amongst Whales? Assessing South Korea's Regional-power Status; August 2009

No 106 Günter Schucher: Where Minds Meet: The "Professionalization" of Cross-Strait Academic Exchange; August 2009

No 105 Alexander Stroh: The Effects of Electoral Institutions in Rwanda: Why Proportional Representation Supports the Authoritarian Regime; July 2009

No 104 Sebastian Huhn: The Culture of Fear and Control in Costa Rica (I): Crime Statistics and Law Enforcement; July 2009

No 103 Günter Schucher: Liberalisierung in Zeiten der Instabilität: Spielräume unkonventioneller Partizipation im autoritären Regime der VR China [Liberalization in Times of Instability: Margins of Unconventional Participation in Chinese Authoritarianism]; June 2009

No 102 Leslie Wehner: Power, Governance, and Ideas in Chile's Free Trade Agreement Policy; May 2009

No 101 Sebastian Huhn: Contested Cornerstones of Nonviolent National Self-Perception in Costa Rica: A Historical Approach; May 2009

No 100 Matthias Basedau, Alexander Stroh: Ethnicity and Party Systems in Francophone SubSaharan Africa; May 2009

No 99 Christian von Soest: Stagnation of a "Miracle": Botswana's Governance Record Revisited; April 2009

No 98 Melanie Hanif: Indian Involvement in Afghanistan: Stepping Stone or Stumbling Block to Regional Hegemony?; April 2009

No 97 Annette Büchs: The Resilience of Authoritarian Rule in Syria under Hafez and Bashar AlAsad; March 2009

No 96 Alexander Stroh: The Power of Proximity: Strategic Decisions in African Party Politics; February 2009

No 95 Robert Kappel, Juliane Brach: Handel, Hierarchien und Kooperation in der Globalisierung [Trade, Hierarchy, and Cooperation in the Age of Globalization]; February 2009

All GIGA Working Papers are available free of charge at www.giga-hamburg.de/workingpapers. For any requests please contact: workingpapers@giga-hamburg.de.

Editor of the Working Paper Series: Martin Beck 